\title{
PROFIL LAMA DIARE PADA ANAK DENGAN PEMBERIAN MINYAK KELAPA MURNI
}

\section{PROFILE OF DURATION OF DIARRHEA IN CHILDREN TREATED WITH VIRGIN COCONUT OIL (VCO)}

\author{
Rahma J. Kusuma \\ SMF IImu Kesehatan Anak RSU. dr. Saiful Anwar Malang
}

\begin{abstract}
Diarrhea in children is still one of the ten major diseases in chirldren. Diarrhea can cause undernutrition, while the undernutrition itself can also cause diarrhea. Until the year of 2000, the prevalence of diarrhe had been decreased, but due to multidimentional crisis it increased up to $27.5 \%$ in 2003. Giving the drugs which directly stop the diarrhea are not recommended, while knowing the definite cause of diarrehea to find the causative treatment still needs several days. Virgin coconut oil (VCO) which contained medium chain saturated fitty acid was used because of its contains of lauric acid and capriac acid, which had antibacterial, antiviral and antiprotozoal action. It also could increase nutritional absorbtion without using enzyme. This longitudinal study was done to know the the profile of duration of diarrhea in children who treated with VCO as an alternative therapy without waiting for laboratory result. Among 42 children under 5 years old who observed in this study, 37 and 5 of them were suffered of acute and chronic diarrhea respectively. This study was only done into the acute diarrhea children while the chronic diarrhea children were only been observed. One case was excluded as he consumed non-VCO drug. Among children with acute diarrhea, 18 were given a teaspoon of VCO two times daily and the other 18 children were given with diet therapy by assumption that the cause of diarrhea was viral. All subjects who drank formula milk, were given low lactose formula milk. Sixteen children which treated with VCO cured within 1 to 2 days and two of them cured within more than 3 days. Among children with diet therapy, 11 children cured within 2 to 3 days and 7 children within more than 3 days $(p<0.05)$. The other five chronic diarrhea children (1-6 months) were cured within 3 to 9 days. VCO can decrease the frequency and duration of acute and chronic diarrhea in children.
\end{abstract}

Key words: Diarrhea in children, VCO, Cure

\section{PENDAHULUAN}

Diare pada anak masih merupakan salah satu masalah kesehatan utama di Indonesia. Setiap tahun, kasus diare selalu menempati 10 besar penyakit terbanyak di Indonesia. Data WHO (2002) menunjukkan bahwa setiap tahun, 11 juta balita di dunia meninggal karena ISPA dan diare. Ditengarai diare terkait erat dengan kondisi kurang gizi pada anak dan $54 \%$ kematian pada diare berkaitan dengan gizi kurang. Diare yang berkepanjangan atau sering kambuh dapat menyebabkan kondisi kurang gizi pada anak, sementara kondisi kurang gizi sendiri juga dapat menimbulkan diare. Data Depkes (2004) menunjukkan bahwa prevalensi kurang gizi dari tahun ke tahun berkurang. Hingga tahun 2000, ditemukan kasus sampai $24,7 \%$. Akan tetapi diduga karena krisis multi dimensi yang melanda Indonesia semenjak krisis moneter di awal tahun 1997, insiden gizi kurang di Indonesia meningkat lagi , yaitu di tahun 2001 sebesar $26,1 \%$, tahun 2002 menjadi $27,3 \%$, dan tahun 2003 mencapai 27,5\% (1). Untuk itu, diperlukan

Jurnal Kedokteran Brawijaya, Vol. XXI, No.3, Desember 2005

Korespondensi: Rahma J. Kusuma; Lab. IKA RSU Dr. Saiful Anwar Malang; telp. 0341-343343; Fax. 0341-369393 usaha pencegahan atau pengobatan agar lama waktu diare tidak berkepanjangan sehingga terjadinya kondisi kurang gizi pada anak yang dapat berakibat pada gangguan pertumbuhan dan perkembangan anak dapat dicegah sedemikian rupa.

Penyebab diare diketahui cukup beragam, yang terbanyak adalah karena infeksi dengan prevalensi berkisar antara $50-75 \%$ (2). Infeksi pada diare dapat disebabkan oleh mikroorganisme virus, bakteri, maupun oleh karena cacing. Salah satu penyebab diare terbanyak, adalah dari golongan virus, yaitu Rota virus. Rota virus menyerang terutama pada anak berusia 9 - 12 bulan dengan insiden hampir $50 \%$ dari seluruh kasus (2). Pengobatan diare yang disebabkan virus ini tidak membutuhkan antibiotik dan hanya membutuhkan terapi suportif untuk mengatasi kehilangan cairan. Sementara itu, untuk diare yang disebabkan oleh bakteri dibutuhkan pengobatan dengan menggunakan antibiotika di samping pengobatan dengan pemberian cairan. Sering kali gejala diare tidak spesifik sehingga menyebabkan kesulitan tersendiri untuk menentukan penyebab diare tersebut, sedangkan untuk dapat memberikan terapi kausatif yang tepat, harus ditemukan dulu penyebabnya melalui serangkaian pemeriksaan laboratorium yang membutuhkan waktu. Hal 
ini dikarenakan apabila terjadi penggunaan antibiotik yang tidak perlu serta tidak tepat dapat menyebabkan ikut matinya bakteri komensal dalam usus yang dapat memperburuk kondisi diare (2). Medikasi anti diare (obatobatan yang menghentikan diare) pada anak-anak seperti kaolin, pektin tidak dianjurkan oleh karena tidak efektif, bahkan dapat berbahaya oleh karena dapat menurunkan kinerja saluran cerna.

Beberapa tahun terakhir telah diperkenalkan berbagai alternatif pengobatan diare dengan menggunakan bahan-bahan alami, seperti penggunaan daun kecubung, daun sirih, daun jambu, kunyit dan minyak kelapa murni. Minyak kelapa murni / virgin coconut oil (VCO) ini dibuat dari kelapa segar dan diproses sedemikian rupa, hingga mengandung asam lemak jenuh rantai sedang, antara lain asam laurat. Asam laurat ternyata hanya didapatkan dalam air susu ibu dengan jumlah sebesar $50 \%$ dari total asam lemak (3). Minyak kelapa ini, adalah satu-satunya minyak yang mengandung asam laurat dengan kadar yang setara pada air susu ibu, yaitu kurang lebih $50 \%$. Asam laurat sangat bermanfaat untuk tubuh, oleh karena di dalam tubuh akan dirubah menjadi monolaurine yang mempunyai efek anti bakteri, anti helicobacter pylori, anti virus, anti protozoa. Asam lemak lain yang ditemukan dalam minyak kelapa, adalah asam capriat yang dalam tubuh akan dirubah menjadi monocaprin dan mempunyai efek antiviral (4). Dari gambaran ini, dapat dilihat bahwa asam laurat mempunyai khasiat sebagai antibiotik alami (5). Efek ini telah lama diteliti dan dibuktikan oleh lebih dari 20 peneliti di Amerika (4).

Dengan berbagai kelebihan yang dimiliki oleh virgin coconut oil, diharapkan minyak ini dapat dipergunakan sebagai terapi adjuvant untuk dapat meringankan gejalagejala diare yang dialami oleh anak, bahkan apabila mungkin dapat dipergunakan sebagai salah satu bentuk terapi kausatif alternatif di samping membantu perbaikan gizi. Akan tetapi masih dibutuhkan penelitian lebih banyak lagi untuk menguji sejauh mana efek minyak kelapa murni terhadap diare pada anak. Penelitian ini bertujuan untuk mengetahui lama diare pada anak dengan berbagai sebab yang diberikan pengobatan VCO saja tanpa disertai pengobatan lain.

\section{METODE}

\section{Desain Penelitian}

Penelitian ini dilaksanakan dengan menggunakan desain deskriptif analitik. Desktiptif dalam hal ini menggambarkan pola lama diare yang terjadi pada anak yang mengkonsumsi VCO selama diare berlangsung. Penelitian ini kemudian menganalisis rata-rata (mean) lama rentang diare, disertai dengan data rentang waktu diare tersering (modus), dan nilai tengah (median) frekuensi diare yang terjadi. Penelitian ini membandingkan pula pengaruh
VCO terhadap lama diare yang terjadi dengan perlakuan kontrol. Perlakuan kontrol dalam penelitian ini, berupa pemberian terapi diet pada pasien diare.

\section{Tempat dan Waktu Penelitian}

Penelitian ini dilaksanakan di Poliklinik Anak RSU dr. Saiful Anwar Malang. Penelitian dilaksanakan dalam jangka waktu 1 bulan, yaitu November hingga Desember 2005.

\section{Populasi dan sampel}

Populasi yang dipergunakan dalam penelitian ini, adalah anak-anak balita yang datang di Poliklinik Anak RSSA dengan keluhan diare dengan berbagai penyebab. Pemilihan sampel dilaksanakan secara acak dengan penyebab yang tidak diidentifikasi terlebih dahulu.

Sampel yang diperoleh, sebanyak 42 anak. 37 anak diare akut, 5 diare khronis. VCO diberikan pada semua anak diare khronis dan 19 anak diare akut, sedangkan 18 yang lain diberikan pengobatan standar. Pasien kemudian dievaluasi dan diberikan informasi untuk kontrol setelah 3 hari. Kedua kelompok yang dibandingkan adalah dengan diare akut, total 36 anak. Sedangkan 5 anak dengan diare kronis yang dilakukan pengamatan dengan pemberian VCO, tidak dibandingkan.

\section{Kriteria inklusi}

- Anak usia 5 tahun ke bawah yang datang dengan keluhan diare, dengan / tanpa muntah dan panas.

- Penderita yang belum menerima dan minum obat apapun, selain VCO yang akan diberikan.

- Penderita kontrol 3 hari setelah pemeriksaan dan pemberian VCO.

- Kesediaan orang tua untuk mengisi inform consent

\section{Kriteria eksklusi}

- Penderita yang diberikan VCO, minum obat lain diluar VCO baik sebelum maupun sesudah pemeriksaan

- Penderita yang tidak kontrol dan tidak termonitor.

\section{Definisi operasional}

1. Penderita yang diberi VCO (Tropico)

Setiap pasien yang datang berobat dengan diare, diberi VCO untuk diminum tiap hari $2 \times 1$ sendok teh $( \pm 7-8$ cc VCO/ sendok). Untuk bayi tetap disarankan minum susu rendah laktosa kemudian disarankan kontrol dalam waktu 3 hari untuk mengetahui perkembangan pengobatan.

2. Diare, didefinisikan sebagai perubahan konsistensi defekasi menjadi cair dengan penambahan frekunsi lebih dari tiga kali sehari, baik disertai maupun tidak disertai muntah dan panas.

- Kriteria sembuh : faeces konsistensi padat \& tanpa darah lendir, dengan frekuensi defekasi maksimum tiga kali sehari.

- Diare akut : diare yang berlangsung kurang dari 2 minggu 
- Diare kronik : diare yang berlangsung lebih dari 2 minggu.

- Terapi diet pada pasien diare, berupa vitamin B complex, pemberian garam oralit, dan advis untuk mengganti susu dengan susu rendah laktosa.

\section{Analisis Data}

Setelah pengumpulan data selesai, dilakukan tabulasi data-data hasil penelitian, kemudian dilakukan analisis rata-rata, nilai median dan nilai modus (Faktor deskripsi populasi). Analisis terhadap kuat hubungan pengaruh VCO terhadap lama diare tidak dilakukan oleh karena penyebab diare tidak diidentifikasi. Sedang kelompok kontrol yang diberi terapi diet juga tidak diidentifikasi penyebab diarenya.

\section{HASIL PENELITIAN}

Dalam penelitian ini 18 kasus diare diberi VCO, tanpa melihat apapun penyebabnya dan pasien minum susu formula yang dianjurkan dalam regimen perawatan pasien dengan diare, yaitu minum susu rendah laktosa, 18 kasus yang lain diberi terapi diet tanpa VCO. Adapun hasil dari pengamatan lama diare pasca pemberian VCO $2 \times 1$ sendok teh dapat diamati dalam Tabel 1.

Tabel 1. Tabel Lama Diare Sebelum dan Setelah Diberikan VCO 2x1 sendok teh

\begin{tabular}{clcc}
\hline \multirow{2}{*}{ No } & \multirow{2}{*}{ Jenis Penyembuhan } & \multicolumn{2}{c}{ Kesembuhan } \\
\cline { 3 - 4 } & & $<3$ hari & $>3$ hari \\
\hline 1. & Konsumsi VCO & 16 & 2 \\
2. & Terapi diet tanpa VCO & 11 & 7 \\
\hline
\end{tabular}

Dari data yang diperoleh, kemudian dianalisis distribusinya dengan SPSS, diketahui bahwa rata-rata lama diare pada anak yang mengkonsumsi VCO, menurun menjadi selama 1,83 hari atau dalam rentang 1-2 hari. Sementara lama diare tersering (modus) setelah mengkonsumsi VCO, adalah sebanyak 1 hari. Pada data penelitian ini masih belum diselidiki faktor-faktor perancu yang memungkinkan memberikan pengaruh pada hasil data, sehingga untuk selanjutnya diperlukan penelitian tambahan yang lebih spesifik dan lebih terkontrol.

Apabila dibandingkan dengan kontrol, dengan menggunakan metode analisis statistik Independent Sample $T$ Test, didapatkan hasil adanya perbedaan lama diare pasca pengobatan dengan VCO dan pemberian terapi diet yang signifikan $(p<0,005)$. Dari hasil analisis statistik, didapatkan bahwa rata-rata hari pasca pengobatan dengan VCO lebih pendek secara bermakna daripada terapi diet .

Analisis varian sampel dengan statistik Levenne's didapatkan varian yang identik untuk masing-masing perlakuan (VCO dan terapi diet ) $(p=0,576)$, sehingga perbedaan rata-rata lama diare yang berbeda secara signifikan dapat lebih ditegakkan, oleh karena sampel yang dipergunakan diasumsikan identik.

Pengamatan pada 5 anak dengan diare khronis dengan pemberian VCO, susu rendah laktose, didapatkan hasil sebagai berikut :

- 2 anak dengan diare selama 1 bulan, sembuh masingmasing dalam 3 hari dan 5 hari.

- $\quad 1$ anak dengan diare selama 2 bulan, sembuh dalam 9 hari.

- 2 anak dengan diare selama 6 bulan, sembuh dalam 2 hari dan 6 hari.

\section{DISKUSI}

Sebagaimana diketahui minyak kelapa telah dipergunakan sejak tahun 1973 di Uganda untuk pengobatan pada anak-anak dengan status gizi kurang (6). Namun jenis minyak kelapa yang dipergunakan di sini berbentuk minyak sayur. VCO juga merupakan salah satu bentuk minyak kelapa, namun masih jarang diaplikasikan dalam pengobatan. Di Indonesia, minyak kelapa biasa dipergunakan dalam bentuk Modisco (Modified Scimmed Coconut Oil), yang dipergunakan sebagai bentuk regimen terapi nutrisi pasien anak dengan malnutirisi. Jenis minyak kelapa yang dipergunakan dalam MODISCO bukan VCO, melainkan menggunakan minyak sayur. Apabila VCO dipergunakan dalam formulasi MODISCO, kemungkinan dapat pula diterapkan untuk memperpendek lama diare, namun sampai saat ini masih belum ditemukan penelitian yang membahas masalah tersebut.

Perbedaan yang penting antara VCO dan minyak sayur adalah VCO mengandung LCFA (Long Chain Unsaturated Fatty Acids) hanya $2 \%$, sedang minyak sayur mencapai $78 \%$. LCFA setelah dikonsumsi dan atau digoreng akan berubah membentuk trans fatty acid dan radikal bebas yang bersifat toksik \& karsinogenik (5).

Penelitian ini diharapkan dapat memberikan gambaran efek minyak kelapa murni dalam mengatasi diare melalui observasi lama diare anak selama mengkonsumsi VCO. Hasil data penelitian deskriptif ini, diharapkan dapat menjadi data acuan untuk diselenggarakannya penelitian lanjutan untuk mengetahui perbandingan efek pemberian VCO dengan terapi obat terhadap diare dengan penyebab tertentu.

Dengan melihat data hasil pemberian VCO diatas, diketahui bahwa VCO cenderung dapat memperpendek waktu, bahkan menghentikan diare secara signifikan bila dibandingkan dengan pengobatan standar. Hal ini dapat dijelaskan karena VCO, menurut penelitian Prof. DR. dr. Waluyo S.,MSc., SpG(K) seorang ahli gizi Universitas Indonesia, mempunyai kandungan asam laurat dan asam capriat sebanyak $50 \%$ dan $7 \%$ dari kandungan seluruh asam lemaknya (5). Dalam 50 cc VCO, terkandung kurang lebih 20-25 gram asam laurat (7). Di antara berbagai asam 
lemak jenuh, asam laurat mempunyai efek antiviral yang tinggi. Sementara itu, asam laurat dan asam kapriat masing-masing di dalam tubuh diubah menjadi monolaurin dan monokaprin, yang keduanya diketahui bersifat antimikroba, anti Helicobacter pilory, antiviral dan antiprotozoa. Mekanisme monolaurin dapat menginaktivasi virus diduga melalui mekanisme perusakan membran fosfolipid kapsul virus, sehingga virus terdesintegrasi $(4,8)$. Oleh karena sifatnya yang mempunyai target sasaran multipel inilah, maka pada penelitian deskriptif awal ini, peneliti tidak mengidentifikasi penyebab diare terlebih dahulu. Namun diharapkan diadakan penelitian lanjutan untuk menguji efek VCO terhadap diare yang lebih spesifik penyebabnya.

Bagian dari asam lemak yang memiliki komponen antiinfektif diketahui pada bagian struktur kimia monogliserida dan free fatty acid. Sifat antimikroba dari monogliserida asam laurat ini telah dikenali sejak tahun 1966 (4). Penelitipeneliti di Center for Disease Control, Amerika (1982) menemukan bahwa asam laurat dapat menginaktivasi virus RNA dan DNA (4). Asam lemak antimikrobial ini diketahui terbentuk in vivo setelah seseorang mengkonsumsi MCFA seperti asam laurat. Namun beberapa peneliti mengungkapkan bahwa efek antimikrobial datang sendiri dari komponen MCFA yang mendisintegrasi membran sel virus yang terdiri dari LCFA (5). Di samping itu, penelitian Isaacs melaporkan bahwa monolaurin tidak menginaktivasi bakteri komensal di usus, akan tetapi menginaktivasi bakteri patogen termasuk Helicobacter pylori dan parasit usus (9).

Penyebab diare sebagian besar adalah virus (Insiden kira-kira sebanyak $50 \%$ ), yang sebenarnya tanpa diobatipun akan sembuh sendiri. Akan tetapi tidak dapat diketahui secara pasti tanpa melalui pemeriksaan klinis. Lama diare oleh karena berbagai penyebab ini juga tidak dapat dipastikan berhenti dalam berapa hari, sehingga resiko dehidrasi tetap dapat terjadi. Dengan pemberian VCO ternyata diare cepat berhenti dan frekuensi defekasi dapat berkurang.

Melihat data penelitian di atas, selain dapat menghentikan diare yang bersifat akut, VCO dapat pula menghentikan diare kronis. Pada anak penderita diare kronis hingga 2 bulan lebih yang mengkonsumsi VCO ternyata sembuh dalam 9 hari. Pada diare kronis, terdapat pertumbuhan bakteri yang berlebihan (overgrowth), malabsorp-si asam empedu, dan malabsorbsi lemak. Pemberian VCO selain mempunyai efek antimikroorganisme dan tidak membunuh bakteri komensal, namun juga mengandung asam lemak jenuh rantai sedang yang bisa langsung diserap tanpa membutuhkan asam empedu dan enzym untuk penyerapannya. Asam lemak jenuh rantai sedang (Medium Chain Trigliceride) diketahui baik untuk penderita dengan malabsorbsi lemak yang berat, yang terdapat pada BBLR, diare kronik, defisiensi protein energi dan gangguan malnutrisi lainnya. Dengan demikian VCO dapat secara efektif berpengaruh terhadap diare kronis, disamping dapat menghentikan diare tersebut, VCO dapat pula meningkatkan status gizi pasien (10).

Keuntungan dari asam lemak jenuh rantai sedang yang terdapat pada minyak kelapa murni adalah absorbsinya tidak membutuhkan enzym, cepat diserap dan menghasilkan energi, dapat diberikan pada gangguan pencernaan, dan membunuh mikroorganisme di usus kecuali bakteri komensal $(3,9)$

Sarjana Faris (2005) menyatakan terdapat fungsi lain asam lemak jenuh rantai sedang yang bermanfaat bagi bayi dan anak, antara lain memudahkan bayi menyerap nutrisi, memperbaiki penyerapan vitamin, mineral, protein yang larut dalam lemak, meningkatkan absorbsi kalsium yang penting bagi pertumbuhan bayi, dan melindungi bayi dari mikroorganisme yang berbahaya (9).

Penelitian ini merupakan penelitian deskriptif, yang masih belum dapat dianalisis kuat pengaruh VCO terhadap diare yang terjadi. Penelitian ini hanya menunjukkan kecenderungan diare yang dapat teratasi dengan pemberian VCO. Menurut pustaka yang ada, VCO dapat membunuh mikroorganisme intraintestinal, baik bakteri, virus, protozoa oleh karena itu pada penelitian ini tidak diidentifikasi penyebab diarenya. Di sisi lain, pemakaian VCO disini selain bertujuan mengatasi diare juga diharapkan dapat memperbaiki gizi anak diare dengan meningkatkan penyerapan nutrisi. Namun untuk mekanisme dan sejauh mana efek peningkatan gizi ini masih memerlukan penelitian lebih lanjut.

\section{KESIMPULAN}

Dari penelitian ini, untuk sementara dapat disimpulkan bahwa lama diare pada anak dapat diperpendek atau dihentikan dengan konsumsi VCO.

Kesimpulan ini masih perlu mendapatkan verifikasi lebih lanjut, terutama untuk uji signifikansi kekuatan efek VCO terhadap lama dan frekuensi diare dengan penelitian yang menggunakan variabel kontrol yang lain, sehingga dapat disimpulkan apakah VCO benar-benar dapat menghentikan diare atau tidak.

\section{SARAN}

Oleh karena penelitian ini masih bersifat deskriptif analitik non spesifik, diharapkan untuk selanjutnya, dapat dilakukan penelitian pada diare secara lebih spesifik dengan mengidentifikasi penyebab diare terlebih dahulu, terutama apabila oleh karena dengan infeksi, yaitu dengan kultur faeces untuk bakteri, dan juga kultur faeces untuk menemukan rota virus. Sebagaimana diketahui hampir $50 \%$ diare non spesifik pada anak, penyebabnya berupa rota virus. Tetapi apapun penyebabnya bakteri (termasuk 
helicobacter pylori, virus maupun protozoa (amuba, giardia lamblia), diketahui dapat diatasi dengan pemberian VCO ini. Harapan selanjutnya, penelitian dapat dilakukan dengan cara-cara penggunaan variabel kontrol terhadap diare yang diidentifikasi penyebabnya melalui kultur faeces. Perlakuan yang diberikan dapat dikelompokkan menjadi tiga, yaitu kelompok yang diberikan VCO, diberikan antibiotik dan kelompok yang diterapi dengan terapi diet .
Dapat pula dipakai desain penelitian yang menggunakan perbandingan antara kultur faeses bakteri dan virus dalam menguji efektifitas VCO terhadap penyebab multipel dengan pemberian perlakuan VCO selama beberapa hari dan dibandingkan dengan regimen terapi biasa, untuk kemudian diuji jumlah biakan bakteri atau virus yang hidup pasca pemberian perlakuan.

\section{DAFTAR KEPUSTAKAAN}

1. UGM. Beban Ganda Masalah Gizi \& Implikasinya Terhadap Kebijakan Pembangunan Kesehatan Nasional . Pengukuhan Guru Besar. www.gizi net/ down load / beban\% 20 ganda\% 20 masalah\%20 gizi pdf. Diakses tanggal 5-22005.

2. Suharyono, Aswitha Boediarso. EM Nalimun : Gastroenterologi Anak Praktis. Jakarta:Balai Penerbit FKUI; $1988 ; 177$ 181.

3. Sutarmi STp, Hartin Rozaline STp. Taklukkan Penyakit dengan VCO, edisi 2. Jakarta: Penebar Swadaya; 2005; 20, 21, 45.

4. Mary Enig PhD. FACN: Coconut in support of Good Health in the 21 th Century USA. http : // www . coconut oil . com / coconut oil 21 st Century htm akses tanggal 3-9-2005

5. Iwan T Budiarso DVW, MSc, PhD, APU. Minyak Kelapa, Minyak Goreng Yang Paling Aman Dan Paling Sehat. 2005; online.Www . medikaholistik. Com/ 2033 / 2004 / 11 / 28 / medika, html , Diakses tanggal 3-9-2005

6. Ratna Indrawati. The Use Of Oil In The Treatment Of Protein Energy Malnutrition In Children. Nutrition in medicine, Surabaya, 1991.

7. Kavitha Venkatraman. Coconut Oil Promises to be Antiviral Agent. online www.financiale $\mathrm{x}$ press. Com/se/daily/20000814 / fco 14018. html. Diakses tanggal 3-9-2005.

8. Trubus Sept 2005. VCO Fakta dari Laboratorium. online : http//www.trubus. Online. Com/ b aca artikel. php, diakses tgl 10-9-2005

9. Faris. Penggunaan Minyak VCO bagi Bayi dan Anak-anak. 2005. online.www.cara sehat. Com / med . php.Diakses tgl 3-9-2005.

10. Behrman, Kliegman, Jenson. Nelson Textbook of Pediatrics, 17 th edition. Philadelphia: Saunders; 2003; 153-157, 249-250. 